\title{
Evaluation and applicability of the three components forage value model in strategic use of grasslands
}

\author{
Fazel Amiri \\ Faculty Member of Scientific Board, Islamic Azad University Bushehr Branch, Iran. \\ Corresponding Author's: famiri@na.iut.ac.ir or famiri@iaubushehr.ac.ir \\ Address: Fazel Amiri, Department of Natural Resources, Islamic Azad University Bushehr \\ Branch, Iran. P.O. Box: 751494433 Bushehr-Iran, Tel: +989131102025. \\ ABSTRACT

\begin{abstract}
Based on the three component mathematical model for numerasing the forage value of grasslands (FVG) the objective of the theoretical research was to investigate the key advantages of the FVG model and to search the applicability of the FVG in planning strategic uses of different grasslands. It is concluded that the FVG model is simple, flexible, it can be used without any constrains, and computerization of the model can present results on FVG already during field investigation. Based on the calculated FVG and grassland categories primary functions of grassland use can be more easily decided. The advisable inputs for higher productivity as well as the technically sound way of utilization in forage production are presented in a table.
\end{abstract}

Keywords: forage value, mathematical model, grassland functions, and production inputs.

\section{INTRODUCTION}

In spite of the emerging new social demands for nonmaterial grassland products and services (environmental protection, nature reservation, aesthetic landscape, amenity purposes, etc.) the productivity of grassland is going to remain in the mainstream of overall grassland use in many regions and countries of Iran. This underlines the importance of forage value of grasslands, however up till now there were only technical and scientific detailed descriptions on this term, which made it difficult to make comparisons between grasslands. Recently (Nagy, 2003, 2005) a simple theoretical model has been developed for numerizing the forage value of grasslands. The purpose of this paper is to evaluate the key advantages of this model and present examples for its applicability in strategic uses of different grasslands with special references to the Iranian conditions.

\section{MATERIAL AND METHODS}

The forage value of grasslands (FVG) is defined as production potential for forage products (milk, meat, etc). The FVG model of Nagy (2005) is a three component theoretical model based on the yield potential, overall herbage quality and the individual ground cover of grassland components and is described by the following mathematical equation:

$$
\mathrm{FVG}_{\circ}=\frac{1}{1000} \times \sum_{i=1}^{n} \mathrm{GC}_{\mathrm{i}} \times \mathrm{YP}_{\mathrm{i}} \times \mathrm{FQ}_{\mathrm{i}}
$$

where; $\mathrm{FVG}_{\mathrm{o}}=$ overall forage value of a grassland, that determine by calculate; $\mathrm{GC}_{\mathrm{i}}=$ individual ground cover of forage species; $\mathrm{YP}_{\mathrm{i}}=$ individual yield potential category of forage species; $F Q_{i}=$ individual forage quality category of species, in each type.

Based on this FVG model theoretical investigations will be used to define the key scientific advantages of the model and to present examples between FVG and primary functions of grassland use, between FVG and way of utilization as well as advisable production inputs for higher productivity of grasslands.

Study area The local and natural situation of the area under the research was mountainous with acute rocky slopes. The area under research is situated in the Zagros region. The total area of the expansion is 8962 hectares. The average high of the area intended is 2936 meters in high above the sea level. The total slop of the area is more area under investigation is from $51^{\circ} 34^{\prime} 54^{\prime \prime}$ to $51^{\circ} 45^{\prime} 53^{\prime \prime} \mathrm{E}$ of latitude from $31^{\circ} 26^{\prime} 19^{\prime \prime}$ to $31^{\circ} 30^{\prime} 28^{\prime \prime} \mathrm{N}$ longitude. The average precipitation during 20 year period of Zagros regain from (1988-2008) is $360 \mathrm{~mm}$. To carry out the research first the intended area in Ghareh Aghach watershed in Isfahan province was selected (Figure 1). 


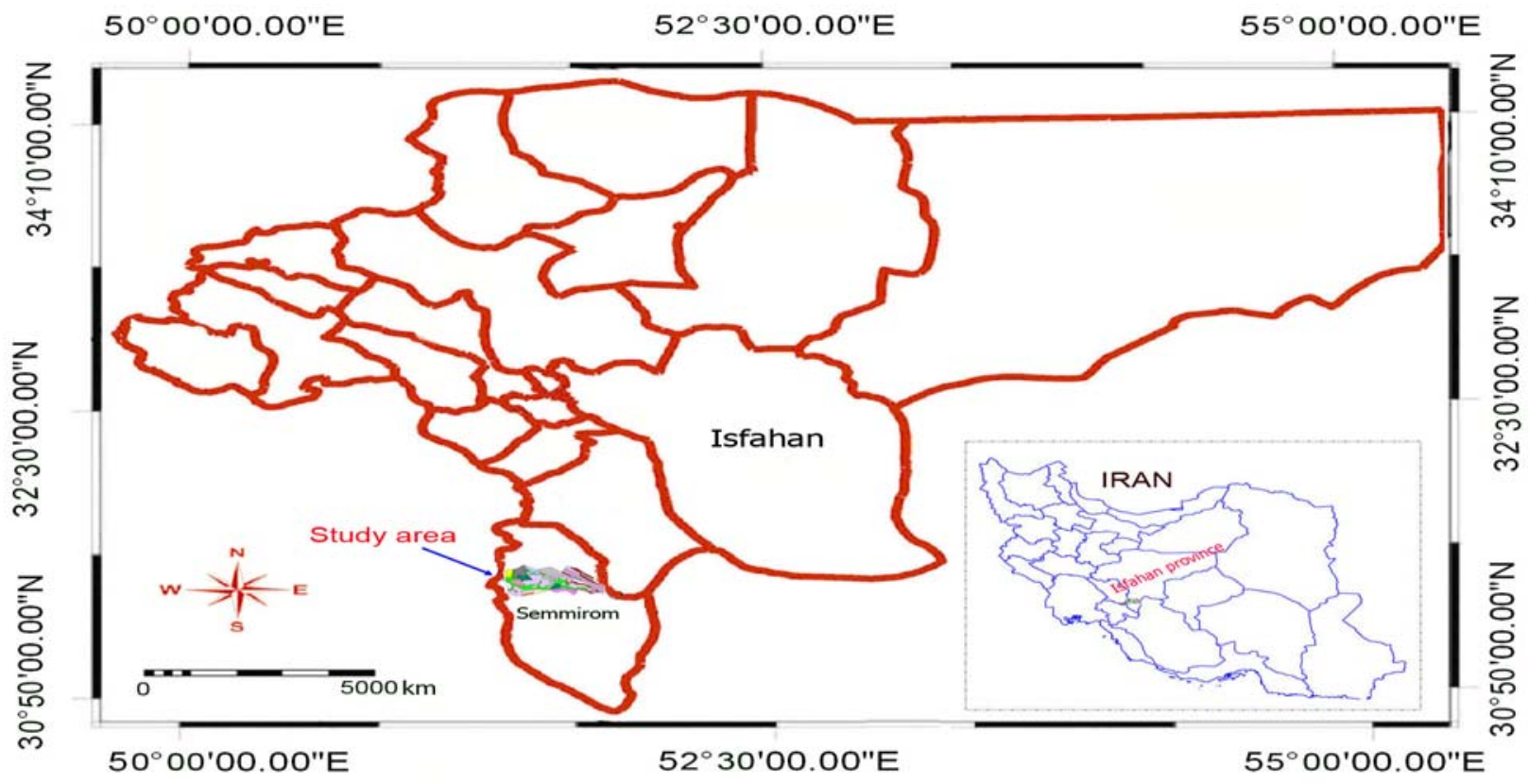

Fig 1. Location of study area

Sampling methods A quantitative survey of the vegetation is carried out during 2007-2008. Considering the conditions of plant development of the area to measure and estimate the intended parameters such as individual ground cover of plants, individual yield potential of plants and individual forage quality of palatable plants were implemented. In every level of altitude, three 200 meter transects were made along and perpendicular of slope. Quadrate samples of one square meter $\left(1 \mathrm{~m}^{2}\right)$ were used to measure plant characteristics (Muller and Ellenberg, 1974). Samples number was determined for each site using the following equation (2):

$$
N=\frac{\mathrm{t}^{2} \times \mathrm{s}^{2}}{(\overline{\mathrm{x}} \times \mathrm{k})^{2}}
$$

Were: $\mathrm{N}$ : number of essential samples, $\mathrm{T}$ : $\mathrm{t}$ student value with $n-1$ and $\infty=5 \%$, S: standard Deviation, $X$ : mean vegetation cover, $\mathrm{N}$ : primary sample number, $\mathrm{K}$ : precision coefficient (usually consider 10\%) (Bonham,1989). According to equation 1, in each sites sampling was done in 3 transect and 60 plots were made. Method of sampling was randomizedsystematic (Amiri, 2009 a, b).

Vegetation cover was sampled with stratified random sampling method and the entities were preliminarily segmented with Physiognomic-floristicecologic method (Khajeddin and Yeganeh, 2008).
The $1 \mathrm{~m}$ by $1 \mathrm{~m}$ quadrate $\left(1 \mathrm{~m}^{2}\right)$ was employed to estimate the ground cover of species $\left(G_{i}\right)$, litter, bare soil, stone and gravel percentages. The measurement of individual forage yield was carried out by cut and weigh $\left(\mathrm{YP}_{\mathrm{i}}\right)$.

Chemical analyses In order to evaluate forage quality $\left(F Q_{i}\right)$ in each quadrate, 15 species for each species at phenological stages of vegetative growth were collected. Each sample selected randomly, clipped and weighted from one centimeter of forage's collar in $500 \mathrm{gr}$ (Amiri, 2009c). Samples were dried at $80^{\circ} \mathrm{C}$ for 24 hours in oven (for determine Dry Matter samples was weighted), then milled and used for chemically analysis. Principal forage analysis values used in ration formulations are: Dry Matter (DM); Crude Protein (CP); Acid Detergent Fiber (ADF); Netural Detergent Fiber (NDF); Digestible Dry Matter (DDM); Metabolizable Energy (ME); Dry Matter Intake (DMI); Relative Feed Value (RFV) (Arzani et al. 2004; Arzani et al. 2005). Crude protein, estimated from total nitrogen concentration, is always important in rations because it is usually the highest-priced nutrient. The formula for estimating CP is ():

$\mathrm{CP}=\% \mathrm{~N} \times 6.25$

Nitrogen content $(\mathrm{N})$ was determined by the microkjeldehal technique using a 'kjeltec' system. Acid Detergent Fiber (ADF) was determined using the method described by Van Soest (1988) with a 'fibertec' system. Netural Detergent Fiber (NDF) 
measured by neutral washing liquid. Digestible Dry Matter (DDM) is measured by Oddy et al. (1983).

\%DDM= $83.58-0.824 \% A D F+2.626 \% \mathrm{~N}$

Metabolizable Energy (ME) was estimated using the equation (5) as described by CSIRO (1990) where $\mathrm{ME} / \mathrm{DM}$ is the Metabolizable Energy in mega joules (MJ) per kg of feed DM.

$\mathrm{ME}=0.17 \% \mathrm{DDM}-2.0$

The Dry Matter Intake (DMI) calculated by equation (6);

$\mathrm{DMI}=\frac{120}{\% \mathrm{ADF}}$

The formula for estimating RFV (Relative Feed Value) from Digestible Dry Matter (DDM) and Dry Matter Intake (DMI) is: (AOAC, 1990)

$$
\mathrm{RFV}=\frac{\mathrm{DDM} \% \times \mathrm{DMI} \%}{1.29}
$$

The model FVG for evaluation of grasslands Steps to be taken for the use of a FVG model.

1. Set categories for forage quality of forage plants
2. Set categories for the productivity of forage plants

3. Calculate the maximum value of a grassland = quality category of forage plants $x$ top productivity category of forage plants

4. Set up categories between 0 and 100 (Table1)

5. Determine the ground cover $\%$ of forage plants with field research.

6. Calculate the FVG.

7. Classify grassland using the calculated FVG (see point 6 and point 4 )

Table 1. The FVG categories for evaluation of Ghareh Aghach grasslands

\begin{tabular}{ll}
\hline & FVG \\
\hline Category & description \\
\hline I. & $75.1-100$ \\
II. & $50.1-75$ \\
III. & $25.1-50$ \\
IV. & $12.1-25$ \\
V. & $0-12$ \\
\hline
\end{tabular}

RESULT

The type of Ghareh Aghach grassland vegetation map, show in Figure (2). The results of yield potential, overall herbage quality, the individual ground cover and overall forage value of Ghareh Aghach grassland showed in Table (2).

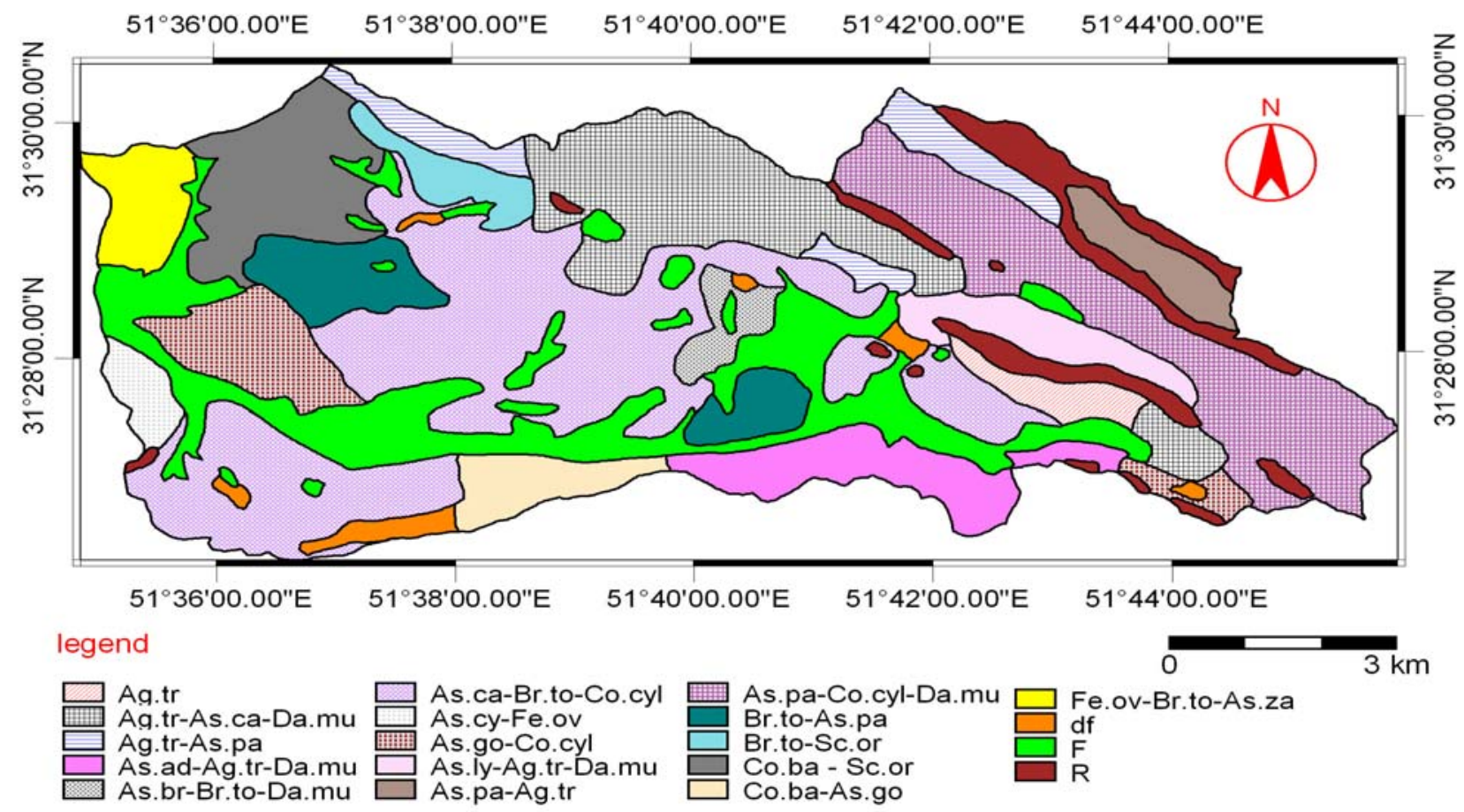

Fig 2. Vegetation type mapping of Ghareh Aghach grasslands 
Agric. Biol. J. N. Am., 2010, 1(5): 785-790

Table2. FVG based on yield potential, ground cover and forage quality in Ghareh Aghach grassland.

\begin{tabular}{|c|c|c|c|c|c|c|}
\hline $\begin{array}{l}\text { Type } \\
\text { code }\end{array}$ & Vegetation type & Area (ha) & $\begin{array}{l}\text { Yield potential } \\
\left(\mathrm{YP}_{\mathrm{i}}\right)(\mathrm{kg} / \mathrm{ha})\end{array}$ & $\begin{array}{l}\text { Ground cover } \\
\left(G C_{i}\right)\end{array}$ & $\begin{array}{l}\text { Forage quality } \\
\left(F Q_{i}\right)\end{array}$ & FVG \\
\hline 1 & Ag.tr & 122.7 & 373.4 & 28.2 & 7.47 & 78.7 \\
\hline 2 & Ag.tr-As.pa & 305.5 & 310 & 30.3 & 7.38 & 69.3 \\
\hline 3 & Ag.tr-As.ca-Da.mu & 898.3 & 289.3 & 26.3 & 7.31 & 55.6 \\
\hline 4 & As.ad-Ag.tr-Da.mu & 385.6 & 262 & 29.7 & 7.2 & 56.0 \\
\hline 5 & As.pa-Ag.tr & 162.7 & 260.1 & 24.8 & 7.05 & 45.5 \\
\hline 6 & As.ly-Ag.tr-Da.mu & 237.5 & 255.3 & 28.9 & 7.29 & 53.8 \\
\hline 7 & As.ca-Br.to-Co.cyl & 2029.7 & 190.8 & 21.1 & 6.84 & 27.5 \\
\hline 8 & As.br-Br.to-Da.mu & 116.2 & 264.6 & 23.2 & 7.15 & 43.9 \\
\hline 9 & As.go-Co.cyl & 362.7 & 206.2 & 18.5 & 6.62 & 25.3 \\
\hline 10 & As.pa-Co.cyl-Da.mu & 968.6 & 188.4 & 16.3 & 6.64 & 20.4 \\
\hline 11 & As.cy-Fe.ov & 105.7 & 283.8 & 23.9 & 7.12 & 48.3 \\
\hline 12 & Br.to-As.pa & 373.1 & 248.8 & 20.8 & 6.58 & 34.1 \\
\hline 13 & Co.ba-As.go & 188.5 & 204.2 & 17.1 & 6.68 & 23.3 \\
\hline 14 & Co.ba-Sc.or & 499.07 & 203.4 & 13.7 & 6.23 & 17.4 \\
\hline 15 & Fe.ov-Br.to-As.za & 212.3 & 313.4 & 25.5 & 7.45 & 59.5 \\
\hline 16 & Br.to-Sc.or & 153.6 & 286.8 & 20.5 & 7.23 & 42.5 \\
\hline
\end{tabular}

The map of the FVG categories for evaluation of study area show in Figure (3).

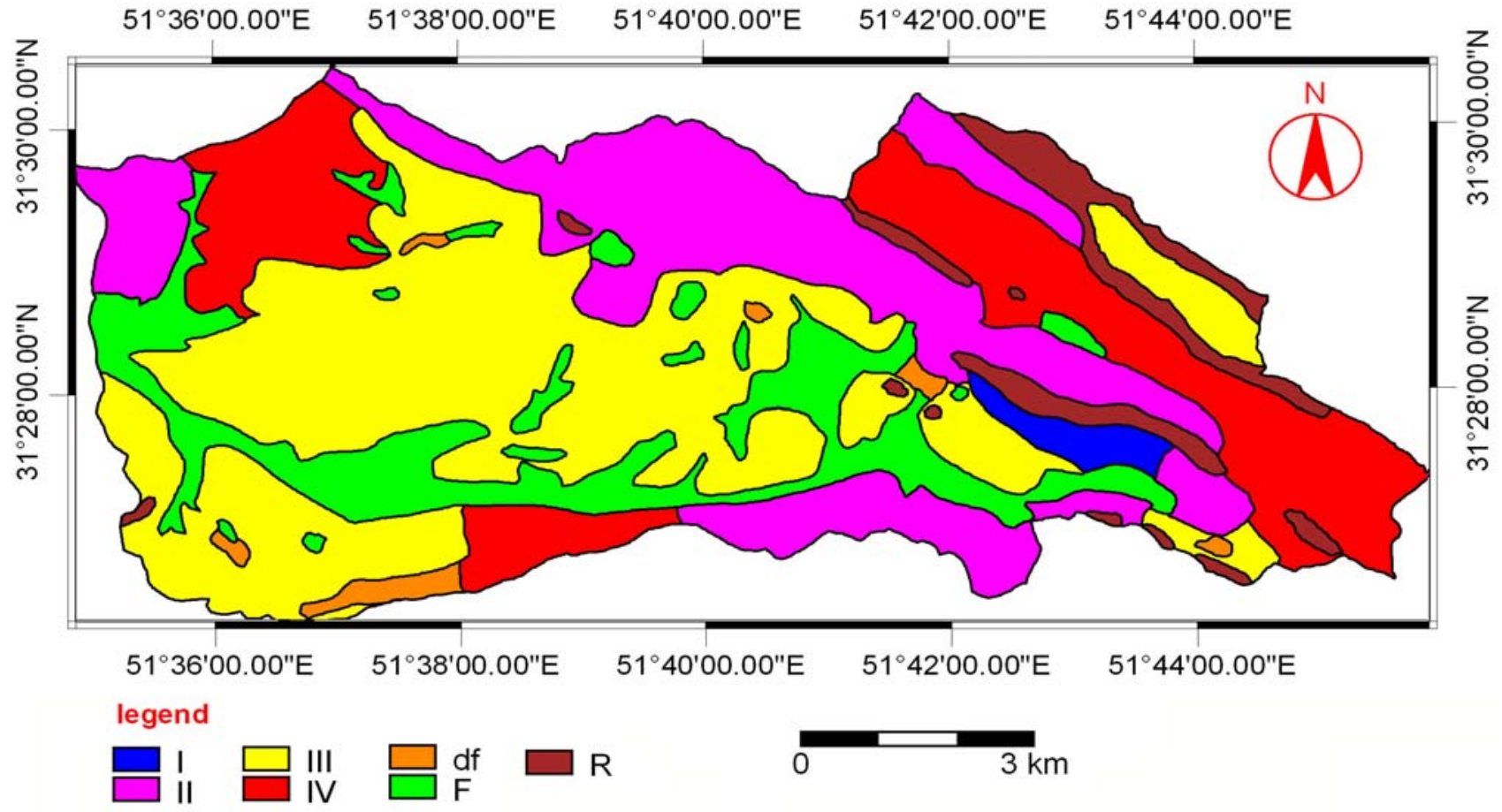

\section{DISCUSSION}

Key scientific advantages of the FVG model: The model is simple enough, as it is based only on three components. Categories for yield potential and overall herbage quality can be set up beforehand. Only ground cover estimation of grassland components (Grant, 1981) needs field investigations. Routine of reliable accuracy for field works can be obtained within of short period of time by the research personal. If the model is computerised, i.e. categories of $\mathrm{YP}$ and $\mathrm{FQ}$ are programmed beforehand only GC should be defined during field work. With the use of a lap top results can be obtained already on site.

The model is flexible, as number of categories for YP and GC, consequently for FVG can be adapted for 
local conditions. Originally 5 categories were established for both elements (Nagy, 2003) of the FVG model but they may be increased or decreased depending on the conditions. However there are some preconditions if we want to evaluate the results of FVG research:

1) it should be based on the three components, i.e. YP, FQ, GC,

2) Categories for $Y P$ and $F Q$ of the herbage components should not only be set up but published as well together with the results.

There are no geographical or location constrains for the use of FVG model because of its flexibility, described before. For this reason the model can be very useful method for the evaluation of grasslands all over the world.
The dynamic of changes in FVG in time can be presented if results on ground cover of grassland components are available. Past data bank on GC of grassland components can successfully be utilized in grassland evaluation.

Forage value and strategic use of grassland: As the FVG model provide a complex (both quantitative $=$ yield potential and qualitative = forage quality) assessment on the production value of grasslands it may be utilized in strategic planning of grassland use. For example, based on the Iranian grassland conditions (Nagy, 2001) the FVG can be combined with the primary functions of future grassland use (Table 3). The advisable inputs for higher productivity as well as the technically sound way of utilization in forage production can also be combined to the value of grasslands (Table 4).

Table3. Scientific correlation between FVG and primary functions of grassland use.

\begin{tabular}{|l|l|l|}
\hline \multicolumn{2}{|c|}{ FVG } & \multirow{2}{*}{ Primary function of future grassland use } \\
\hline I. & description & \\
\hline II. & very good & intensive forage production \\
\hline III. & good & medium level or intensive forage production \\
\hline IV. & medium & medium level forage production \\
\hline V. & very poor & environmental protection, nature reservation, or extensive forage production \\
\hline
\end{tabular}

Table4. Advisable production inputs and utilization systems according to the forage value of grasslands.

\begin{tabular}{|l|l|l|l|}
\hline FVG & Description & $\begin{array}{l}\text { Advisable production inputs } \\
\text { for higher productivity }\end{array}$ & Technically sound way of utilization \\
\hline I. & very good & $\begin{array}{l}\text { high inputs (e.g. fertilization, } \\
\text { irrigation, etc.) }\end{array}$ & $\begin{array}{l}\text { intensive grazing (sheep, goat, dairy or beef cattles) } \\
\text { cutting for silage (May) and for hay (midseason) }\end{array}$ \\
\hline II. & good & $\begin{array}{l}\text { moderate level on inputs (i.e. } \\
\text { fertilization) adapted to } \\
\text { ecological conditions }\end{array}$ & $\begin{array}{l}\text { less intensive grazing (sheep, goat, beef or dairy cattles) } \\
\text { cutting for hay (May) }\end{array}$ \\
\hline III. & medium & $\begin{array}{l}\text { Grassland improvement and } \\
\text { sustaining farming/cultivation }\end{array}$ & $\begin{array}{l}\text { medium grazing (beef cattles, dairy heifers, intensive } \\
\text { sheep and goat) }\end{array}$ \\
\hline IV. & poor & $\begin{array}{l}\text { grassland renovation (oversee } \\
\text { ding) or improvement and } \\
\text { sustaining farming/cultivation }\end{array}$ & $\begin{array}{l}\text { extensive grazing of sheep and goat, or beef cattles (in } \\
\text { Spring) }\end{array}$ \\
\hline V. & very poor & $\begin{array}{l}\text { grassland renovation and } \\
\text { sustaining farming/cultivation }\end{array}$ & $\begin{array}{l}\text { extensive grazing of sheep and goat or local breeds of } \\
\text { cattle }\end{array}$ \\
\hline
\end{tabular}

\section{CONCLUSIONS}

As presented in Table 3, there are positive correlation between the foragel value of grasslands and the intensity of grassland use expressed in primary function of grasslands.

For the higher productivity of grasslands (Table 2) extra inputs (improvement or renovation works) are necessary beside the regular production inputs (fertilization, irrigation) if the forage value is declining. At the same time the technically sound way of utilization drops from intensive dairy grazing to extensive sheep grazing.
These results support, that FVG may be a useful tool to assist strategic planning of grassland use as regards primary functions of grassland use, production inputs of higher productivity and sound ways of utilization. However FVG is calculated from the sward composition so, before planning future grassland use and farming systems grassland surveys need to be done in the given area or region. 


\section{REFERENCES}

Ahmadi A. H. Arzani and A. A. Jafari. (2005). Determination and composition of forage quality of five species in different phenplogical stages in Alborz rangelands (IRAN). Proceedings of the XX International Grassland Congress, Ireland, page: 292.

Amiri F. (2009). A GIS model for determination of water resources suitability for goats grazing. Afr J Agric Res. 4 (1):14-20,

Amiri F. (2009). A model for classification of range suitability for sheep grazing in semi-arid regions of Iran. Journal of Livestock Research for Rural Development 21 (5). p. 68-84.

Amiri F. E. Gavili and Soffianian A. R. (2009). Determine forage quality of 12 range species. $4^{\text {th }}$ Iranian National Conference of Range and Range Management.

AOAC. (1990). Officinal methods of analysis of the assosiation of official analitical chemists. 15 th ed. Washington D.C.USA.

Arzani H. M. Zohdi E. Fish G. H. Zahedi Amiri A. Nikkhah and Wester. D. (2004). Phenological effects on forage quality of five grass species. J. of Range Management 57(6): 624- 630 .

Bonham C. (1989). Measurement terrestrial vegetation. 2nd edition, John Wiley and Sons Inc, New York. pp. 338. ISBN: 0471048801, 9780471048800.

Grant S. A. (1981). Sward components. In: Hodgson J. et. al. (eds) Sward measurements handbook. British Grassland Society Grassland Research institute, Hurley, Maidenhead, Berkshire, UK, pp 71-92.
Khajeddin S. J. and Yeganeh H. (2008). Plant communities of the Karkas Hunting-Prohibited Region, Isfahan-Iran. Plant, Soil and Environ J, 54 (2). p.347-358.

Muller-Dombois D. and Ellenberg. H. (1974). Aims and Method of Vegetation Ecology. John wiley sons, New York

Nagy G. (2001). FAO Country Pasture/Forage Resource Profile for Hungary. FAO Grassland. http://www.fao.org/WAICENT/FAOINFO/AGRICULT/A GP/AGPC/doc/Counprof/hungary.htm

Nagy G. (2003). A gyepterületek mezőgazdasági értékének meghatározása (Determination of the agricultural value of grasslands). In: Jávor A. (ed) Legeltetéses állattartást! DE ATC, Debrecen, 271-280.

Nagy G. (2005). A simple theoretical model for calculating agricultural value of grasslands. In: O'Mara et al. (eds) XX. International Grassland Congress: Offered papers. Wageningen Academic Publishers, The Netherlands, 893.

Oddy V. H. Robards G. E. and Low S. G. (1983). Prediction of Invivo Matter Digestibility from the Fiber Nitrogen Content of a Feed, In Feed Information and Animal Production, eds. G.E. Robards, and R. G. Pakham Commonwealth Aagricultural Bureaux, Australia, pp. 395-398.

Redfearn D. and Zhang H. (2008). Forage Quality Interpretations. Oklahoma Cooperative Extension Service, PSS-2117. pp. 1-4. http://osufacts.okstate.edu

Standard Committee on Agriculture. (1990). Feeding Standards for Australian Livestock Ruminants, CSIRO, Australia.

Van Soest P. J. (1988). Nutritional Ecology of the Ruminant. Cornell University Pres, Itheca, NY.

\begin{tabular}{ll}
\hline Appendix & \\
\hline Ag.tr & Agropyron trichophoum \\
Ag.tr-As.pa & Agropyron trichophoum-Astragalus parroaianus \\
Ag.tr-As.ca-Da.mu & Agropyron trichophoum-Astragalus canesens- Daphne macronata \\
As.ad-Ag.tr-Da.mu & Astragalus adsendence-Agropyron trichophoum-Daphne macronata \\
As.pa-Ag.tr & Astragalus parroaianus-Agropyron trichophoum \\
As.ly-Ag.tr-Da.mu & Astragalus lycioides-Agropyron trichophoum-Daphne macronata \\
As.ca-Br.to-Co.cyl & Astragalus canesens-Bromus tomentellus-Cousinia cylianderica \\
As.br-Br.to-Da.mu & Astragalus brachycalyx-Bromus tomentellus-Daphne macronata \\
As.go-Co.cyl & Astragalus gossipianus-Cousinia cylanderica \\
As.pa-Co.cyl-Da.mu & Astragalus parroaianus-Cousinia cylanderica-Daphne macronata \\
As.cy-Fe.ov & Astragalus cyclophylus-Ferula ovina \\
Br.to-As.pa & Bromus tomentellus-Astragalus parroaianus \\
Co.ba-As.go & Cousinia bachtiarica-Astragalus gossipianus \\
Co.ba-Sc.or & Cousinia bachtiarica-Scariola orientalis \\
Fe.ov-Br.to-As.za & Ferula ovina-Bromus tomentellus-Astragalus zagrosicus \\
Br.to-Sc.or & Bromus tomentellus-Scariola orientalis \\
df & Agriculture \\
$\mathrm{F}$ & Garden \\
$\mathrm{R}$ & Rock \\
\hline
\end{tabular}

